\section{Growth and Yield of Vegetable Soybean (Edamame) in Mississippi}

\author{
Lingxiao Zhang ${ }^{1}$ and S. Kyei-Boahen
}

ADDITIONAL INDEX wORDs. edible soybean, maturity group, net returns

Summary. Soybean (Glycine max) grown as a vegetable is gaining in popularity in the U.S. and demand is expected to increase over the long term. However, information on production in the U.S. is limited because most of the product is imported. Field experiments were conducted at Stoneville, Miss., in 2004 and 2005 to evaluate the production and yield potential and to estimate the net returns for sustainable production in the Mississippi Delta. In 2004, four vegetable soybean varieties were evaluated and 23 varieties were evaluated in 2005. The varieties varied from maturity group III to VII. The late-maturing varieties were generally taller, had more nodes/plant, pods/plant, and fresh green pod yield at R6 stage (full seed) than the early-maturing varieties. Fresh green bean yield ranged from 1438 to $19,119 \mathrm{lb} /$ acre in 2004 . The mean bean yield for the 18 Apr. 2005 planting was $26,538 \mathrm{lb} /$ acre compared with a mean of $18,131 \mathrm{lb} /$ acre for the 10 May 2005 planting. Interaction occurred between planting date and variety as well as soil type and variety for all the variables evaluated. 'Envy' produced the lowest yield, whereas 'Garden Soy 01', 'Garden Soy 21', 'Midori Giant', 'Mojo Green', and 'Moon Cake' produced the highest fresh bean yield. The estimated net returns, using the Mississippi State Budget Generator as a guide, indicated more than twice the returns from growing the regular commodity soybean. The data suggest that vegetable soybean can fit well into the existing cropping system and could be a viable alternative crop for growers in the Mississippi Delta who want to capitalize on a niche market.

$\mathrm{V}$ egetable soybean, also called edamame, is becoming increasingly popular in the U.S. as a result of the high nutritional value and health benefits. These soybeans are harvested when the pods are fully filled and still green. Fresh or frozen vegetable soybeans are eaten just like green peas (Pisum sativum). The pods are boiled and the beans added to stews, mixed vegetables, soups, stir-fried vegetables, and so on. They are very popular in Asian countries, including China (Guan, 1977), Japan (Benziger and Shanmugasundaram, 1995), and Korea (Hong et al., 1984). National consumption in Japan averaged 159,900 tons annually (Nguyen, 1997) and demand in the U.S. is estimated to be 14,877 tons per year by 2010 (Johnson, 2000).

Vegetable soybeans differ from regular soybeans in many ways. They are usually large-seeded with mild taste, tender, and easily digestible. Fresh green soybeans also have a com-

We thank Dr. R. Bernard at the University of Illinois, Dr. An Hang at Washington State University, and Dr. T. Devine at U.S. Department of AgricultureAgriculture Research Service in Maryland for providing the seeds for this study. We also thank Ms. J. Dong for her assistance with data collection.

${ }^{1}$ Corresponding author. E-mail: lzhang@drec.msstate.edu bination of low oil and relatively high protein content (Brar and Carter, 1993). They also contain a lower percentage of gas-producing starches. Harvesting vegetable soybeans at the right time is critical for maximum texture and flavor (Johnson, 2000; Wszelaki et al., 2005), because loss of quality occurs when pods turn yellow. Beans reach their maximum sweetness $\approx 1$ month after flowering. The quality is best when the pod is plump and bright green, similar to snow peas (P. sativum) in color.

Soybean breeders in the U.S. have crossed some of the large-seeded Asian varieties with adapted U.S. grain varieties and have developed several varieties that are better adapted to the growing conditions in the U.S. A number of promising vegetabletype soybean lines adapted to various growing conditions have been se- lected by scientists from several state universities in Illinois, Ohio, Washington, Virginia, Arkansas, etc, as well as from the USDA. Scientific information on vegetable soybean production is very limited, especially in the midsouthern U.S., although potential advantages for growing exist. These advantages include: 1 ) vegetable soybeans in the midsouthern U.S. can be planted early to take advantage of early market opportunities and longer marketing season; 2) some vegetable soybeans can reach $\mathrm{R} 6$ stage (full seed and still green) (Fehr and Caviness, 1977) before late July or early August when drought stress normally occurs and thus avoid drought stress; and 3 ) there are many small soybean farmers in the midsouthern U.S. who can easily adopt vegetable soybean production and may be able to find a niche market for this high-value alternative crop. The objectives of this study were to evaluate the adaptation and yield potential of vegetable soybeans and to determine viability as an alternative crop in Mississippi.

\section{Materials and methods}

Field experiments were conducted at the Delta Research and Extension Center, Stoneville, Miss., on clay loam soil in 2004 and on clay loam (fine, smectitic, thermic Chromic Hapludert) and clay (very fine, smectitic, thermic Chromic Epiaquert) soils in 2005. In 2004, four vegetable soybean varieties, including three commercial varieties ('Besweet 2020', 'Butterbean', and 'Envy') and one USDA variety ('Moon Cake'), were planted on 7 June. In 2005, 23 vegetable soybean varieties were planted on 18 Apr. on clay loam soil and also on clay loam and clay soils on 10 May. Seed sources and varieties planted in 2005 as well as estimated maturity group (MG) based on growth duration in Stoneville are listed in Table 1. Soybean varieties

\begin{tabular}{llll}
\hline $\begin{array}{l}\text { Unit } \\
\text { To convert U.S. to SI, } \\
\text { multiply by }\end{array}$ & U.S. unit & SI unit & $\begin{array}{l}\text { To convert SI to U.S., } \\
\text { multiply by }\end{array}$ \\
\hline 0.4047 & $\mathrm{acre}(\mathrm{s})$ & $\mathrm{ha}$ & $2.471 \mathrm{l}$ \\
0.3048 & $\mathrm{ft}$ & $\mathrm{m}$ & 3.2808 \\
2.54 & inch(es) & $\mathrm{cm}$ & 0.3937 \\
0.4536 & $\mathrm{lb}$ & $\mathrm{kg}$ & 2.2046 \\
1.1209 & $\mathrm{lb} / \mathrm{acre}$ & $\mathrm{kg} \cdot \mathrm{ha}^{-1}$ & 0.8922 \\
$\left({ }^{\circ} \mathrm{F}-32\right) \div 1.8$ & ${ }^{\circ} \mathrm{F}$ & ${ }^{\circ} \mathrm{C}$ & $\left(1.8 \times{ }^{\circ} \mathrm{C}\right)+32$
\end{tabular}


Table 1. Vegetable soybean varieties, seed sources, and the estimated maturity groups (MG) range used for the 2005 experiments in Stoneville, Miss.

\begin{tabular}{|c|c|c|c|c|}
\hline \multirow[b]{2}{*}{ Variety } & \multirow[b]{2}{*}{ Source ${ }^{\mathrm{z}}$} & \multicolumn{2}{|c|}{ Planting date } & \multirow{2}{*}{$\begin{array}{l}\text { Estimated } \\
\text { MG range }\end{array}$} \\
\hline & & 18 Apr. & 10 May & \\
\hline Bellesoy & Wannamaker & Yes & Yes & $>$ VII \\
\hline Besweet 2020 & Vermont & Yes & Yes & L-III - E-IV \\
\hline Butter Bean & Johnny's & Yes & Yes & L-III - E-IV \\
\hline Envy & Johnny's & Yes & Yes & $<\mathrm{III}$ \\
\hline Green Lion & Wannamaker & Yes & Yes & $>$ VII \\
\hline Garden Soy 01 & UI & Yes & No & E-IV \\
\hline Garden Soy 11 & UI & No & Yes & L-III - E-IV \\
\hline Garden Soy 21 & UI & Yes & Yes & L-IV \\
\hline Garden Soy 22 & UI & No & Yes & L-IV \\
\hline Garden Soy 24 & UI & Yes & No & L-III - E-IV \\
\hline Garden Soy 31 & UI & Yes & Yes & E-IV \\
\hline Garden Soy 41 & UI & Yes & No & L-III - E-IV \\
\hline Garden Soy 42 & UI & Yes & No & L-III \\
\hline IA2025 & Cooper & No & Yes & L-III - E-IV \\
\hline Midori Giant & Wannamaker & Yes & Yes & L-III - E-IV \\
\hline Mojo Green & Wannamaker & Yes & Yes & $\mathrm{L}-\mathrm{V}-\mathrm{E}-\mathrm{VI}$ \\
\hline Moon Cake & USDA/ARS & Yes & Yes & L-V - E-VI \\
\hline WSU-618 & Washington State & No & Yes & E-IV \\
\hline WSU-706 & Washington State & No & Yes & L-III \\
\hline WSU-710A & Washington State & Yes & Yes & E-IV \\
\hline WSU-729 & Washington State & No & Yes & $\mathrm{E}-\mathrm{V}$ \\
\hline WSU-730A & Washington State & Yes & Yes & L-III - E-IV \\
\hline WSU-743 & Washington State & Yes & Yes & E-IV \\
\hline
\end{tabular}

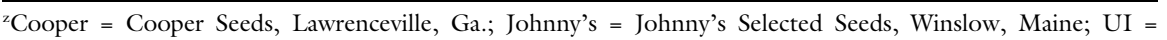
University of Illinois, Urbana-Champaign; USDA/ARS = U.S. Department of Agriculture/Agriculture Research Service, Beltsville, Md.; Vermont = Vermont Bean Seed Co., Randolph, Wis.; Wannamaker = Wannamaker Seeds, Inc., St. Matthews, S.C.; Washington State = Washington State University, Pullman.

${ }^{y} \mathrm{~L}=$ late, $\mathrm{E}=$ early.

have been classified into 13 MGs expressed as Roman numerals. The MG 000 varieties are the earliest in maturity and MG $X$ varieties are the latest. The experimental design for both years was a randomized complete block with four replications. Each plot consisted of four 20 -ft-long rows planted on 20 -inch spacing at a seeding rate of six seeds per foot. The seeding rate was based on results from previous studies using regular soybean at the same location (unpublished data). The emergence, growth, and development as well as disease incidence were monitored throughout the growth period. The fields were irrigated three times ( 1 inch of water at each irrigation) during June and July through an overhead lateral move system. Weeds were controlled using field cultivation and hand weeding. Date of emergence and dates reaching individual phenologic growth stages, specifically flowering (Rl), full seed (R6), and physiological maturity (R8) (Fehr and Caviness, 1977), were recorded. Plants were hand-harvested at R6 stage from onehalf of each plot (i.e., from two center rows) and the other half left to reach full maturity to determine the entire growth duration and maturity group of individual varieties. Other variables recorded at R6 stage include plant height (measured from the soil level to the tip of the stem), number of nodes, number of pods/plant, and number of seeds/pod. The variables were determined from 10 plants randomly sampled from the middle of each plot, and the means were used in the analysis. Data for each experiment were analyzed separately using general linear model procedures of SAS (version 9.1; SAS Institute, Cary, N.C.) because of the differences in the varieties as well as the number of varieties used in the experiments. However, the 2005 data for nine varieties that were planted on both 18 Apr. and 10 May on the clay loam soil were analyzed across planting date. Similarly, data for varieties planted on both clay loam and clay soils on 10 May 2005 were combined. For the analysis combined across planting date on clay loam soil, the planting date, variety, and planting date by variety interaction were considered fixed. Similarly, soil type, variety, and soil type by variety interaction were fixed factors for the analysis combined across soil type. Blocks were nested either within planting date or soil type and were considered random. Means were separated using Fisher's protected least significant difference (LSD) at 0.05 level of probability.

\section{Results and discussion}

Vegetable soybean had similar growth and development characteristics as traditional soybean with growth duration depending on the maturity group. In 2004, varieties 'Besweet 2020', 'Butterbean', and 'Envy' flowered 29 to $34 \mathrm{~d}$ after planting (DAP) and reached R6 suitable for harvest as green beans 58 to $64 \mathrm{DAP}$. The flowering duration was similar to that for the traditional soybean late maturity group (MG) III and early MG IV planted at the same time period (Table 2). 'Moon Cake' took $44 \mathrm{~d}$ to reach flowering and $101 \mathrm{~d}$ to complete seed fill (R6) and was comparable to the traditional late $M G \mathrm{~V}$ to early $\mathrm{MG}$ VI variety planted at the same period.

Results from the 2005 studies indicated that the estimated MG for the varieties used ranged from groups III through VII (Table 1). Of the 23 varieties evaluated, 16 were considered early varieties. Two varieties, 'Bellesoy' and 'Green Lion', were very late-maturing (later than 'MG VII') and were discarded because they are not suitable for production in the Mississippi Delta. The other latematuring varieties reached full seed stage (ready for harvest as green beans) 98 to $126 \mathrm{DAP}$, whereas the early varieties took 70 to $92 \mathrm{~d}$ (Tables 3-5). The period from planting to R6 for the early varieties in particular varied between planting dates in 2005. For example, the early varieties reached R6 earlier when planted in April than in May and this could be the result of sensitivity to day length (Cober et al., 1996). Soybean is a short-day plant in which flowering occurs only when the day length is shorter than the critical photoperiod. The plants sown in April were exposed to relatively short days and likely causing early flowering and thus hastening the days to R6 when compared with the May planting date (Zhang et al., 2004). The days to R6 for 
Table 2. Plant height, fresh green bean yield and yield components at R6, and estimated maturity group range (MG) of vegetable soybean planted on 7 June 2004 at Stoneville, Miss. ${ }^{2}$

\begin{tabular}{|c|c|c|c|c|c|c|}
\hline Variety & $\begin{array}{l}\text { Plant ht } \\
\text { (inches) }^{\mathrm{y}}\end{array}$ & $\begin{array}{c}\text { Nodes } \\
\text { (no./plant) }\end{array}$ & $\begin{array}{c}\text { Pods }^{\mathrm{x}} \\
\text { (no./plant) }\end{array}$ & $\begin{array}{c}\text { Seeds } \\
\text { (no./pod) }\end{array}$ & $\begin{array}{c}\text { Pod fresh } \\
\text { wt }(1 \mathrm{l} / \text { acre })^{w}\end{array}$ & $\begin{array}{l}\text { Estimated } \\
\text { MG range }\end{array}$ \\
\hline Besweet 2020 & $10.1 \mathrm{~b}$ & $9.2 \mathrm{~b}$ & $16.9 \mathrm{~b}$ & $2.03 \mathrm{a}$ & $7164 \mathrm{~b}$ & L-III - E-IV \\
\hline Butterbean & $9.1 \mathrm{cb}$ & $8.6 \mathrm{~b}$ & $14.4 \mathrm{~b}$ & $1.88 \mathrm{~b}$ & $4046 c$ & L-III - E-IV \\
\hline Envy & $8.3 \mathrm{c}$ & $8.0 \mathrm{c}$ & $15.2 \mathrm{~b}$ & $1.81 \mathrm{~b}$ & $1438 \mathrm{c}$ & $<$ III \\
\hline Moon Cake & $28.7 \mathrm{a}$ & $18.9 \mathrm{a}$ & $57.1 \mathrm{a}$ & $1.87 \mathrm{~b}$ & $19,119 a$ & $\mathrm{~L}-\mathrm{V}-\mathrm{E}-\mathrm{VI}$ \\
\hline Mean & 14.1 & 11.2 & 25.9 & 1.90 & 7942 & \\
\hline
\end{tabular}

${ }^{2}$ Plant height was measured from the soil level to the tip of the main stem. Fresh pods were harvested by hand.

${ }^{y} 1$ inch $=2.54 \mathrm{~cm}$.

${ }^{x}$ Green pods with seeds.

${ }^{\mathrm{w}} \mathrm{l} \mathrm{lb} / \mathrm{acre}=1.1209 \mathrm{~kg} \cdot \mathrm{ha}^{-1}$

${ }^{\mathrm{V}} \mathrm{L}=$ late, $\mathrm{E}=$ early.

'Mojo Green' and 'Moon Cake' were fairly similar for both planting dates, but 'WSU-710A' and 'WSU-743' reached R6 $7 \mathrm{~d}$ earlier when planted in May than in April. Further research is required to elucidate the photoperiodic responses of these varieties.

Plant growth and development were faster in 2004 than 2005 because of the warmer temperatures at planting in June 2004 relative to that in April and early May 2005. The average maximum and minimum air temperatures for June 2004 at Stoneville, Miss., were 87 and $71^{\circ} \mathrm{F}$, respectively, compared with 75 and $55^{\circ} \mathrm{F}$ for Apr. 2005 and 83 and $62{ }^{\circ} \mathrm{F}$ for May 2005 (National Weather Service, Stoneville Experiment Station). The late-maturing varieties were generally taller, had more nodes/plant, pods / plant, and total fresh pod weight than the early maturing varieties (Tables 2-5).
Fresh green bean yield in 2004 for 'Mooncake' was 19,119 lb/acre, whereas that for the early maturing varieties ranged from 1438 to 7164 $\mathrm{lb} /$ acre. In 2005 , fresh bean yields ranged from $7577 \mathrm{lb} /$ acre for 'Envy' to $39,163 \mathrm{lb} /$ acre for 'Mojo Green' (Table 3 ). The yield difference between the varieties planted in both 2004 and 2005 is primarily the result of the greater number of pods per plant for the experiments. Plant height and number of nodes per plant for 'Besweet 2020', 'Butterbean', and 'Envy' were generally similar in 2004 and 2005 , but the pods per plant were $2.3,3.2$, and 2.7 times, respectively, higher in 2005 than 2004. However, all the yield components data for 'Moon Cake' were higher in 2005 compared with 2004. Although we did not have June 2005 data for a direct yield comparison between
2004 and 2005 , it is likely the yield differences between years were the result of differences in planting date. It is clear from the 2005 study that early planting improved yield (e.g., Tables 3 and 4). In a simulation model, Egli and Bruening (1992) demonstrated that in the absence of water stress, lower level of insolation during the reproductive growth stage was the major cause of soybean yield losses from delayed plantings. Application of supplementary water in the present study minimized any potential yield limitation by moisture deficit, but yield losses were not eliminated, indicating that other factors may be implicated. Studies in Ohio indicated that traditional soybean yield declined as planting date delayed after the first of May (Beuerlein, 1988), and similarly, Heatherly (2005) concluded that

Table 3. Plant characteristics, yield, and yield components at R6 (full seed stage) of vegetable soybean planted on clay loam soil on 18 April 2005 at Stoneville, Miss.

\begin{tabular}{|c|c|c|c|c|c|c|}
\hline Variety & $\begin{array}{l}\text { Plant ht } \\
\text { (inches) }^{\mathrm{y}}\end{array}$ & $\begin{array}{c}\text { Nodes } \\
\text { (no./plant) }\end{array}$ & $\begin{array}{c}\text { Pods }^{\mathrm{x}} \\
\text { (no./plant) }\end{array}$ & $\begin{array}{c}\text { Seeds } \\
\text { (no./pod) }\end{array}$ & $\begin{array}{c}\text { Pod fresh } \\
\text { wt (lb/acre) }\end{array}$ & $\begin{array}{l}\text { Time to } \\
\text { R6 (d) }\end{array}$ \\
\hline Besweet 2020 & $9.5 \mathrm{fg}$ & $9.1 \mathrm{fg}$ & $37.4 \mathrm{fg}$ & $2.1 \mathrm{~b}$ & $21,087 \mathrm{f}$ & 87 \\
\hline Butter Bean & $7.5 \mathrm{gh}$ & $9.0 \mathrm{fg}$ & $44.3 \mathrm{ef}$ & $2.1 \mathrm{~b}$ & $21,028 \mathrm{f}$ & 86 \\
\hline Envy & $9.5 \mathrm{fg}$ & $7.7 \mathrm{i}$ & $27.0 \mathrm{~h}$ & $2.0 \mathrm{bcd}$ & $7577 \mathrm{~h}$ & 70 \\
\hline Garden Soy 01 & $20.9 \mathrm{~b}$ & $14.6 \mathrm{~b}$ & $65.5 \mathrm{c}$ & $2.2 \mathrm{a}$ & $32,298 \mathrm{bcd}$ & 113 \\
\hline Garden Soy 21 & $11.8 \mathrm{def}$ & $8.5 \mathrm{ghi}$ & $49.9 \mathrm{de}$ & 1.9 cde & $34,640 \mathrm{ab}$ & 99 \\
\hline Garden Soy 41 & $10.5 \mathrm{ef}$ & $8.7 \mathrm{gh}$ & $53.7 \mathrm{de}$ & $1.9 \mathrm{cde}$ & 28,906 bcde & 99 \\
\hline Garden Soy 42 & $11.7 \mathrm{def}$ & $9.7 \mathrm{ef}$ & $58.2 \mathrm{~cd}$ & $1.9 \mathrm{cde}$ & 27,783 cde & 87 \\
\hline Midori Giant & $10.6 \mathrm{ef}$ & $10.1 \mathrm{e}$ & $53.3 \mathrm{de}$ & $2.1 \mathrm{bc}$ & 30,528 bcde & 87 \\
\hline Mojo Green & $14.9 \mathrm{c}$ & $10.5 \mathrm{de}$ & $82.1 \mathrm{~b}$ & $2.2 \mathrm{a}$ & $39,163 \mathrm{a}$ & 124 \\
\hline Moon Cake & $57.3 \mathrm{a}$ & $25.7 \mathrm{a}$ & $97.7 \mathrm{a}$ & $2.1 \mathrm{bc}$ & $33,678 \mathrm{abc}$ & 124 \\
\hline WSU-710A & $12.6 \mathrm{cde}$ & $11.8 \mathrm{c}$ & $67.5 \mathrm{c}$ & $2.1 \mathrm{bc}$ & $27,768 \mathrm{cde}$ & 98 \\
\hline
\end{tabular}

${ }^{2}$ Plant height was measured from the soil level to the tip of the main stem. Fresh pods were harvested by hand.

${ }^{\mathrm{y}} 1 \mathrm{inch}=2.54 \mathrm{~cm}$.

${ }^{x}$ Green pods with seeds.

${ }^{\mathrm{w}} 1 \mathrm{lb} /$ acre $=1.1209 \mathrm{~kg} \cdot \mathrm{ha}^{-1}$. 
Table 4. Plant characteristics, yield, and yield components at R6 (full seed stage) of vegetable soybean planted on clay loam soil on 10 May 2005 at Stoneville, Miss. ${ }^{z}$

\begin{tabular}{lcccccc}
\hline Variety & $\begin{array}{c}\text { Plant ht } \\
\text { (inches) }\end{array}$ & $\begin{array}{c}\text { Nodes } \\
\text { (no./plant) }\end{array}$ & $\begin{array}{c}\text { Pods }^{\mathbf{x}} \\
\text { (no./plant) }\end{array}$ & $\begin{array}{c}\text { Seeds } \\
\text { (no./pod) }\end{array}$ & $\begin{array}{c}\text { Pod fresh } \\
\text { wt (lb/acre) }\end{array}$ & $\begin{array}{c}\text { Time to } \\
\text { R6 (d) }\end{array}$ \\
\hline Besweet 2020 & $9.5 \mathrm{e}$ & $8.8 \mathrm{c}$ & $37.1 \mathrm{cde}$ & $2.0 \mathrm{~cd}$ & $17,357 \mathrm{bcd}$ & 91 \\
Garden Soy 21 & $10.7 \mathrm{cde}$ & $9.2 \mathrm{c}$ & $28.5 \mathrm{e}$ & $2.0 \mathrm{~cd}$ & $14,919 \mathrm{~cd}$ & 87 \\
Garden Soy 24 & $8.9 \mathrm{ef}$ & $9.0 \mathrm{c}$ & $32.5 \mathrm{de}$ & $2.1 \mathrm{bc}$ & $16,512 \mathrm{bcd}$ & 90 \\
Garden Soy 41 & $10.2 \mathrm{cde}$ & $9.7 \mathrm{c}$ & $40.7 \mathrm{~cd}$ & $2.1 \mathrm{bc}$ & $18,480 \mathrm{bcd}$ & ND \\
IA2025 & $13.7 \mathrm{~b}$ & $13.4 \mathrm{~b}$ & $47.4 \mathrm{bc}$ & $2.0 \mathrm{~d}$ & $15,661 \mathrm{~cd}$ & 90 \\
Midori Giant & $9.9 \mathrm{de}$ & $9.7 \mathrm{c}$ & $38.6 \mathrm{cde}$ & $2.2 \mathrm{a}$ & $19,545 \mathrm{bc}$ & ND \\
Moon Cake & $48 \mathrm{a}$ & $25.4 \mathrm{a}$ & $120.2 \mathrm{a}$ & $2.0 \mathrm{~d}$ & $36,755 \mathrm{a}$ & 125 \\
WSU-710A & $11.9 \mathrm{bcd}$ & $13.7 \mathrm{~b}$ & $58.0 \mathrm{~b}$ & $2.2 \mathrm{a}$ & $19,119 \mathrm{bcd}$ & 91 \\
WSU-730A & $6.7 \mathrm{f}$ & $7.3 \mathrm{~d}$ & $32.5 \mathrm{de}$ & $1.8 \mathrm{e}$ & $13,876 \mathrm{~d}$ & 94 \\
WSU-743 & $12.3 \mathrm{bc}$ & $12.7 \mathrm{~b}$ & $47.3 \mathrm{bc}$ & $2.2 \mathrm{a}$ & $21,814 \mathrm{~b}$ & 91 \\
Mean & 14.18 & 11.89 & 48.28 & 2.06 & 19,404 & 95 \\
\hline
\end{tabular}

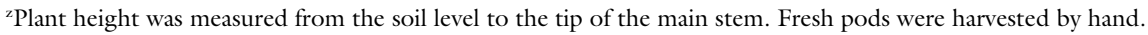

${ }^{y} l$ inch $=2.54 \mathrm{~cm}$.

${ }^{x}$ Green pods with seeds.

w $1 \mathrm{lb} /$ acre $=1.1209 \mathrm{~kg} \cdot \mathrm{ha}^{-1}$

$\mathrm{ND}=$ not determined.

Table 5. Plant characteristics, yield, and yield components at R6 (full seed stage) of vegetable soybean planted on clay soil on 10 May 2005 at Stoneville, Miss. ${ }^{\mathrm{z}}$

\begin{tabular}{|c|c|c|c|c|c|c|}
\hline Variety & $\begin{array}{l}\text { Plant ht } \\
\text { (inches) }^{\mathrm{y}}\end{array}$ & $\begin{array}{c}\text { Nodes } \\
\text { (no./plant) }\end{array}$ & $\begin{array}{c}\text { Pods }^{\mathrm{x}} \\
\text { (no./plant) }\end{array}$ & $\begin{array}{c}\text { Seeds } \\
\text { (no./pod) }\end{array}$ & $\begin{array}{c}\text { Pod fresh } \\
\text { wt (lb/acre) }\end{array}$ & $\begin{array}{l}\text { Time to } \\
\text { R6 (d) }\end{array}$ \\
\hline Besweet 2020 & $11.6 \mathrm{fg}$ & $9.9 \mathrm{f}$ & $41.4 \mathrm{gh}$ & $1.8 \mathrm{i}$ & $18,429 \mathrm{~cd}$ & 92 \\
\hline Envy & $14.0 \mathrm{def}$ & $14.1 \mathrm{~b}$ & $55.3 \mathrm{~cd}$ & $2.3 \mathrm{abc}$ & $21,101 \mathrm{bc}$ & 87 \\
\hline Garden Soy 11 & $14.4 \mathrm{cde}$ & $13.0 \mathrm{de}$ & 33.7 hi & $2.4 \mathrm{a}$ & $14,449 \mathrm{efg}$ & 92 \\
\hline Garden Soy 21 & $12.3 \mathrm{efg}$ & $12.5 \mathrm{e}$ & $50.7 \mathrm{cdef}$ & $1.9 \mathrm{ghi}$ & $18,980 \mathrm{~cd}$ & ND \\
\hline Midori Giant & $10.5 \mathrm{gh}$ & $10.0 \mathrm{f}$ & $52.5 \mathrm{cde}$ & $2.1 \mathrm{efg}$ & $23,245 \mathrm{~b}$ & 92 \\
\hline Mojo Green & $17.6 \mathrm{~b}$ & $12.5 \mathrm{e}$ & $76.0 \mathrm{a}$ & $2.0 \mathrm{efg}$ & $29,633 \mathrm{a}$ & 126 \\
\hline Moon Cake & $56.9 \mathrm{a}$ & $25.8 \mathrm{a}$ & $64.3 \mathrm{~b}$ & $2.0 \mathrm{efg}$ & $18,032 \mathrm{cde}$ & 126 \\
\hline WSU-618 & $10.8 \mathrm{~g}$ & $14.1 \mathrm{bc}$ & $46.2 \mathrm{efg}$ & $2.2 \mathrm{bcd}$ & $16,931 \mathrm{de}$ & 93 \\
\hline WSU-706 & $11.4 \mathrm{fg}$ & $13.7 \mathrm{bcd}$ & $43.0 \mathrm{fg}$ & $1.9 \mathrm{hi}$ & $12,100 \mathrm{fg}$ & 92 \\
\hline Mean & 14.5 & 12.4 & 46.6 & 2.0 & 16,858 & 97 \\
\hline
\end{tabular}

${ }^{2}$ Plant height was measured from the soil level to the tip of the main stem. Fresh pods were harvested by hand.

${ }^{y} 1$ inch $=2.54 \mathrm{~cm}$.

${ }^{x}$ Green pods with seeds.

${ }^{\mathrm{w}} 1 \mathrm{lb} / \mathrm{acre}=1.1209 \mathrm{~kg} \cdot \mathrm{ha}^{-1}$.

$\mathrm{ND}=$ not determined.

yields of soybean planted after May in Stoneville, Miss., were lower compared with yields for earlier planting dates. The yield data reported for some of the varieties in the present study (Tables 3-5) compare well with values ranging from 13,038 to $19,646 \mathrm{lb} /$ acre for 14 vegetable soybean genotypes grown in Fort Valley, Ga. (Rao et al., 2002). In North Dakota, Duppong and HattermanValenti (2005) reported a mean marketable green soybean yield of 7121 $\mathrm{lb} /$ acre for 'Butterbean' and 7644 $\mathrm{lb} / \mathrm{acre}$ for 'Envy' grown in 2003 and 2004. The differences in yield among the three locations could be the result of differences in soil and weather conditions, planting date, and genotype.

The agronomic variables at full seed stage differed among varieties, and there was evidence that plant growth and yield for the $18 \mathrm{Apr}$. 2005 planting date were better than the 10 May 2005 planting date. For the nine varieties combined across planting dates on the clay loam soil, early planting increased plant height, number of pods/plant, and pod fresh weight (Table 6). However, whereas the number of nodes did not differ between the planting dates, the number of seeds per pod was higher when planted on 10 May. Interaction occurred between planting date and variety indicating that the varieties did not performance similarly across planting date (Table 6). For example, unlike the other varieties, yield for 'Moon Cake' was higher when planted on 10 May than on 18 Apr. In addition, planting date did not affect the yield of 'WSU-730A.' There was also evidence of soil type by 
Table 6. Analysis of variance for plant characteristics, yield, and yield components at R6 (full seed stage) of vegetable soybean cultivars planted on clay loam soil on 18 Apr. and 10 May 2005 at Stoneville, Miss.

\begin{tabular}{lrrcrrr}
\hline Source & df & Plant ht & Nodes/plant & Pods/plant & Seeds/pod & $\begin{array}{r}\text { Pod fresh } \\
\text { wt/acre }\end{array}$ \\
\hline \multicolumn{7}{c}{$P>\mathrm{F}$} \\
\hline Planting date (P) & 1 & $<0.0001$ & 0.7681 & 0.0003 & 0.0047 & $<0.0001$ \\
Cultivar (C) & 8 & 0.0002 & 0.0062 & $<0.0001$ & $<0.0001$ & 0.0002 \\
$\mathrm{P} \times \mathrm{C}$ & 8 & $<0.0001$ & $<0.0001$ & $<0.0001$ & $<0.0001$ & $<0.0001$ \\
\hline
\end{tabular}

variety interaction (Table 7 ). From the fresh green bean yield standpoint, 'Moon Cake', 'WSU-710A', 'WSU730A', and 'WSU-743' performed better on clay loam soil, whereas 'Midori Giant' and 'Garden Soy 21' did better on clay soil. Yields of 'Besweet 2020' and 'IA2025' were similar on both clay loam and clay soils. In general, 'Garden Soy 01', 'Garden Soy 21', 'Midori Giant', 'Mojo Green', and 'Moon Cake' were the best-yielding varieties, whereas 'Envy' was the least-yielding variety. Thus, these five high-yielding varieties would be considered the most viable varieties for the Mississippi Delta if profitability was based on yield alone. The varieties were evaluated under irrigation conditions and yields may be lower under dry land conditions. In addition, consumer preferences for pod appearance, bean taste and texture have been documented (Johnson, 2000; Kelley and Sanchez, 2003; Lee and Hwang, 1998; Wszelaki et al., 2005) and could influence the price and the willingness to purchase a particular vegetable soybean variety. Thus, additional studies would be necessary to evaluate irrigation requirements, and also pod appearance and sensory quality attributes in relation to desirability, to make a valid conclusion about the most profitable varieties for the Mississippi Delta.

The pods on plants allowed to reach full maturity exhibited high degree of shattering, thus uniform emergence and timely harvest of the dry beans may be essential for edamame seed producers. No disease symptoms were visually observed suggesting that yields in both years were not limited by disease pressure. The short growing periods of some of the vegetable soybean varieties, in particular 'Envy', make them suitable for use in a double-crop system or for growers who want to capitalize on the early market.

One of the many challenges producers face when considering new crops is the lack of reliable profitability estimates. Differences in production practices and harvest cost greatly influence returns, and in particular, the actual market prices for new crops are often difficult to estimate (Ernst and Woods, 2001). Using the Mississippi State Budget Generator (Laughlin and Spurlock, 2005) as a guide, economic analyses were conducted to evaluate returns over variable and fixed production costs for vegetable soybean. We estimated total production cost (cost of seeds, fuel, irrigation, hired labor for harvesting, and so on, cooling, repair and maintenance of equipment etc) as $\$ 3472 /$ acre (Table 8). This did not include costs for land, management, and overhead. Harvesting was done manually by hand because of lack of harvesting machinery; hence, most of the labor cost was associated with harvesting. Farm gate price for fresh beans was estimated as one-third of the prices on the local retail market (average clay soils on 10 May 2005 at Stoneville, Miss. Stoneville, Miss., in 2004.
$\$ 1.50 / \mathrm{lb})$. Conservative estimation, therefore, indicated that for an average yield of $7942 \mathrm{lb} /$ acre in 2004 , net returns of $\$ 499 /$ acre above the specified costs could be obtained from vegetable soybean production. Conservative budget estimates for vegetable soybean production in Kentucky indicated potential net returns of $\$ 400$ to $\$ 2500 /$ acre for wholesale fresh market beans (Ernst, 2001). The estimated net returns for the present study indicated about twice the returns (average \$150-250/acre) from regular soybean production in the Mississippi Delta.

\section{Conclusion}

Soybean as a green vegetable has a great potential in the U.S. The results from this study indicated that vegetable soybean could be successfully grown in the Mississippi Delta. Growth and yield for the mid-April and early May planting dates were better than the early June planting. Considering the growth duration, groups III and IV may fit well to the growing season in the midsouthern U.S. and will also take advantage of the early market demand. Yields and estimated net returns from vegetable soybeans are promising in Mississippi, but the major problems are the laborintensive nature of production, limited consumer base or well-established

Table 7. Analysis of variance for plant characteristics, yield, and yield components at R6 (full seed stage) of vegetable soybean cultivars planted on clay loam and

\begin{tabular}{lrrcrrr}
\hline Source & df & Plant ht & Nodes/plant & Pods/plant & Seeds/pod & $\begin{array}{r}\text { Pod fresh } \\
\text { wt/acre }\end{array}$ \\
\hline Soil type (S) & 1 & $<0.0001$ & 0.0021 & 0.0217 & 0.0031 & 0.0059 \\
Cultivar (C) & 8 & 0.0067 & 0.0132 & $<0.0001$ & $<0.0101$ & $<0.0001$ \\
S $\times$ C & 8 & $<0.0001$ & $<0.0001$ & $<0.0001$ & $<0.0001$ & $<0.0001$ \\
\hline
\end{tabular}

Table 8. Estimated budget for 1 acre $(0.4$ ha) of vegetable soybean grown in

Item

Average yield

Farm gate price

Gross returns

Preharvest costs (seeds, cultivation, weed control, irrigation, and repair and maintenance of equipment)

Harvesting, handling and storage including cooling

Total specific cost

Net returns above specified cost

${ }^{2} 1 \mathrm{lb} / \mathrm{acre}=1.1209 \mathrm{~kg} \cdot \mathrm{ha}^{-1}, \$ 1.00 / \mathrm{lb}=\$ 2.2046 / \mathrm{kg}, \$ 1.00 /$ acre $=\$ 2.471 \mathrm{l} / \mathrm{ha}$
Estimated amount ${ }^{\mathrm{z}}$

$7942 \mathrm{lb}$

$\$ 0.50 / \mathrm{lb}$

$\$ 3971$

$\$ 1972$

$\$ 1500$

$\$ 3472$

$\$ 499$ 
marketing channels, and lack of processing facilities. However, as awareness of the nutritional and health benefits of vegetable soybean increases, these problems may be solved to help increase production. Research aimed at variety selection based on flavor, texture, and other characteristics could help increase consumer preference and consumption.

\section{Literature cited}

Benziger, V. and S. Shanmugasundaram. 1995. Taiwan's frozen vegetable soybean industry. Asian Vegetable Research and Development Center, Taipei, Taiwan. Tech. Bul. No. 22.

Beuerlein, J.E. 1988. Yield of determinate and indeterminate semidwarf soybean for several planting date, row spacings, and seeding rates. J. Prod. Agr. 1:300-303.

Brar, G.S. and T.E. Carter, Jr. 1993. Soybean (Glycine max L. Merril), p. 427763. In: G. Kalloo and B.O. Bergh (eds.). Genetic improvement of vegetable crops. Pergamon Press, N.Y.

Cober, E.R., J.W. Tanner, and H.D. Voldeng. 1996. Genetic control of photoperiod response I early-maturing, near-isogenic soybean lines. Crop Sci. 36:601-605.

Duppong, L.M. and H. HattermanValenti. 2005. Yield and quality of vegetable soybean cultivars for produc- tion in North Dakota. HortTechnology 15:896-900.

Egli, D.B. and W. Bruening. 1992. Planting date and soybean yield: Evaluation of environmental effects with a crop simulation model: SOYGRO. Agr. For. Meteorol. 62:19-29.

Ernst, M. 2001. Marketing new crops: Edamame. 10 Apr. 2006. <http://www. uky.edu/Ag/HortBiz/pubs/edamame_ marketing.pdf $>$.

Ernst, M. and T. Woods. 2001. Marketing challenges for emerging crops in Kentucky: Vegetable soybeans. 10 Apr. 2006. <http://www.uky.edu/Ag/ HortBiz/pubs/mkt_vegsoy.pdf>.

Fehr, W.R. and C.E. Caviness. 1977. Stages of soybean development. Spec. Rept. 80. Iowa State Univ. Coop. Ext. Serv., Ames.

Guan, P.Z. 1977. Vegetable bean, p. 333-338. In: S.X. Li (ed.). Vegetable cultivation, South China. Chinese Agricultural Publishers, Beijing.

Heatherly, L.G. 2005. Midsouthern USA soybean yield affected by maturity group and planting date. 7 Sept. 2006. <http:// www.plantmanagementnetwork.org/ $\mathrm{sub} / \mathrm{cm} / \mathrm{research} / 2005 /$ soy $/>$.

Hong, E.H., S.D. Kim, and Y.H. Hwang. 1984. Production and use of and research on soybeans in Korea. Trop. Agr. Res. Ser. 17:81-93.

Johnson, D. 2000. Edamame: Westerners develop a taste for Japanese soybean. Eng. Technol. Sustainable World 7:11-12.
Kelley, K.M. and E.S. Sanchez. 2003. Use of sensory evaluation to assess consumer perception and acceptance of edamame (Glycine max) cultivars. HortScience 38:779(Abstr.).

Laughlin, D.H. and S.R. Spurlock. 2005. User's guide for the Mississippi State Budget Generator version 6.0 for Windows. 10 Dec. 2005. <http://www. agecon.msstate.edu/laughlin/msbg/ userguide6.pdf $>$.

Lee, J.D. and Y.H. Hwang. 1998. Quality evaluation for vegetable use in local soybean cultivars with various seed coat color. Korean J. Crop Sci. 43:83-88.

Nguyen, V.Q. 1997. Edamame (vegetable green soybean). 10 Mar. 2006. <http:// www.rirdc.gov.au/pub/handbook/ edamame.html>.

Rao, M.S.S., A.S. Bhagsari, and I.A. Mohamed. 2002. Fresh green seed yield and seed nutritional traits of vegetable soybean genotypes. Crop Sci. 42:19501958.

Wszelaki, A.L., J.F. Delwiche, S.D. Walker, R.E. Liggett, S.A. Miller, and M.D. Kleinhenz. 2005. Consumer liking and descriptive analysis of six varieties of organically grown edamame-type soybean. Food Quality Preference 16:651-658.

Zhang, L.X., J. Zhang, C.E. Watson, Jr., and S. Kyei-Boahen. 2004. Developing phenological prediction tables for soybean. 7 Sept. 2006. <http://www. plantmanagementnetwork.org/pub/ $\mathrm{cm} /$ research/2004/tables/>. 